\title{
THE EFFECTS OF CHEMICAL AND ORGANIC FERTILIZER APPLICATIONS ON FORAGE YIELD AND QUALITY OF SMOOTH BROME (BROMUS INERMIS L.) UNDER IRRIGATED AND NON-IRRIGATED CONDITIONS
}

\author{
GENC LERMI, A. ${ }^{1 *}-$ ERDOGdu, $\dot{I}^{2}{ }^{2}-$ AltinOK, S. $^{3}$ \\ ${ }^{l}$ Department of Crop and Animal Production, Vocational School, University of Bartın \\ Bartın, Turkey \\ ${ }^{2}$ Eskisehir Transitional Zone Agricultural Research Institute, Eskisehir, Turkey \\ ${ }^{3}$ Department of Field Crops, Faculty of Agriculture, Ankara University, Ankara, Turkey \\ *Corresponding author \\ e-mail: aysegenclermi@gmail.com; phone: +90-505-815-3474; fax: +90-378-227-8875 \\ (Received 26 $6^{\text {th }}$ Jun 2018; accepted $31^{\text {st }}$ Aug 2018)
}

\begin{abstract}
The aim of this research is to examine the effects of chemical and organic fertilizer applications on the forage yield and quality of smooth brome. The research was conducted in two separate experiments under irrigated and non-irrigated conditions in a randomized complete blocks design with three replications. Ammonium sulphate was used as chemical fertilizer, manure and poultry manure as organic fertilizer and Vicia sativa $\mathrm{L}$ as green manure. Under irrigated and nonirrigated conditions, the impacts of different fertilizer applications on the smooth brome's height of plant, crude protein rate, crude protein yield, green grass yield and dry matter yield were evaluated. According to the results of the research, while the average dry matter yield was obtained to be $3.94 \mathrm{t}$ $\mathrm{ha}^{-1}$ under irrigated conditions, it was obtained as $1.70 \mathrm{t} \mathrm{ha}^{-1}$ under non-irrigated conditions. The peak values under irrigated conditions were obtained from chemical fertilizer application. However, under non-irrigated conditions the highest values were obtained from organic fertilizer applications. Consequently, considering the impacts of using organic fertilizers on the ecological properties of the soil in the long term, it was concluded that the yield difference between chemical fertilizer and organic fertilizer under irrigated conditions was at tolerable level.
\end{abstract}

Keywords: manure, poultry manure, chemical fertilizer, dry matter yield, organic forage

\section{Introduction}

Plant production methods not damaging the natural resources and ecosystem should be preferred, while it is aimed to obtain maximum yield in unit area from plant production. One of the most frequently used methods in increasing productivity is fertilization. Especially, with the use of chemical fertilizers, the importance and value of organic fertilizers were ignored. The most applied method in improving the physical properties of soil and maintaining its sustainability is the addition of organic matters (Bender et al., 1998). Organic fertilizer improved the physical, chemical and biological properties of the soil (Shiralipour et al, 1992; Carpenter-Boggs et al., 2000; Marinari et al., 2000) as well as increasing the plant yield and quality Yolcu (2011). Sonmez et al. (2008) emphasized that the use of chemical fertilizer was essential in agricultural production despite some of its adverse effects, but that the arising problems could be reduced by paying attention to the amount and time of application and by supporting with organic fertilizer. The sustainability and profitability of plant production shall only be achieved by increasing chemical fertilization and organic fertilization made 
according to the available nutrient content of our soil that was exposed to intensive chemical fertilizer use. With the use of organic fertilizer, organic matter of the soil increases, and thus the physical, chemical and biological properties of the soil improve. Manure, poultry manure, compost and green fertilizer are used for organic fertilization purpose.

According to the researches, it is seen that the effects of chemical fertilizers on the increase of forage yield are higher, whereas the advantages of organic fertilizers in terms of productivity, cost and ecology decrease the attractiveness of chemical fertilizers. Nazli et al. (2014) found that the use of organic fertilizers and chemical fertilizers met the forage need, while at the same time it could reduce the dependence on inorganic fertilizers in agricultural areas. Thus, it was reported that it had positive impact on both the soil productivity and the environment. Bulluck et al. (2002) examined of the effects of the organic and synthetic fertility amendments on the soil in organic and conventional farm. The researchers reported that the yield is not affected by the fertilizer applications within the first year, but the organic production yield is higher than the conventional production yield within the second year. Furthermore, the researchers emphasized that the useful microorganisms in the soil increase, the pathogen population decrease, the soil organic substance, the total carbon and the cation exchange capacity (CEC) increase and thus the soil quality is improved with the alternative fertilizer applications. Emerenciano Neto et al. (2016) concluded that manure was lower than chemical fertilizer as a nitrogen source but that manure was available to be used in order to reduce cost and environmental impacts. Razec et al. (2009) stated that through fertilization made with manure, more economic efficiency was obtained, the yield increased by $75-123 \%$ and vegetation density and seed formation capacity increased.

Among the forage legumes, the smooth brome is one of the plants that can be included in the planting pattern under arid and semi-arid conditions due its temperaturetolerance and drought-tolerance. In addition, smooth brome is the leading forage plant that can be used alone or in mixtures with legumes under irrigated and arid conditions (Serin et al., 1998).

In the last decade, organic animal production has been rapidly increasing in many countries around the world. In fourteen countries of the European Union, Cereals and forage crops are cultivated on more than $80 \%$ of arable under organic farming (Golijan, 2017). The most important need for organic livestock farming is the production of organic forage plants (Yolcu, 2011). The production of organic forage crops plays an important role in organic livestock farming especially in terms of the ecological and economic sustainability of the farms (Will, 2012). As in conventional agriculture, the forage plant cultivation constitutes about $70 \%$ of production costs in organic livestock farming. Organic meadow-pasture areas constitute $62 \%$ of total organic agricultural areas in the world and organic forage plants production areas constitute 5\%. In total, organic roughage production areas constitute $67 \%$ of the world's organic agricultural production areas. Organic roughage production in our country is 44206 tonnes in organic meadows and 315053 tonnes in organic forage plants (Yolcu et al., 2014). Moreno-Resendez et al. (2017) reported that in the organic forage crops production, organic fertilizer increases the forage yield and quality of corn.

Smooth brome can be considered as alternative forage plant especially in the regions where stiff winters are dominant due to its resistance to cold and semi-arid ecologies. Researchers conducted in different locations on yield and quality of smooth brome. 
Albayrak and Ekiz (2005) obtained the dry matter and crude protein yields of smooth brome under arid conditions as $1.28 \mathrm{t} \mathrm{ha}^{-1}$ and $0.142 \mathrm{t} \mathrm{ha}^{-1}$, respectively. Karakurt and Ekiz (2000) obtained the highest dry matter and crude protein yields of smooth brome, which was subjected to nitrogen fertilizer and manure under arid conditions, from $120 \mathrm{~kg} \mathrm{ha}^{-1}$ of nitrogenous fertilizer $3 \mathrm{t} \mathrm{ha}^{-1}$ applications. Serin et al. (1998) stated that the highest dry matter yield of smooth brome was obtained in the first year and that the yield decreased in the $2^{\text {nd }}$ and $3^{\text {rd }}$ years. Hongrong et al. (2000) reported that the smooth brome aboveground yield increases with the sewage-sludge application.

The aim of this research is to determine the effects of chemical and organic fertilizer applications on the forage yield and quality of smooth brome. In addition, the effectiveness of different fertilizer applications under irrigated and dried conditions were also determined. The data obtained shall be of importance in terms of applications that have gained importance in recent years such as sustainable agriculture, low-input agriculture, good agricultural practices and organic agriculture.

\section{Materials and methods}

\section{Locations, soil and climate}

This research was conducted in 2003 and 2004 in the smooth brome experiment field that was established in 2002 in Field Crops Department of Faculty of Agriculture, Ankara University, Turkey. The geographical coordinates of the experiment field are within $39^{\circ} 57^{\prime}$ northern latitude, $32^{\circ} 52^{\prime}$ eastern longitude and $860 \mathrm{~m}$ altitude. The soil properties of the experimental field have clayed-loamy texture, with $\mathrm{pH}=7.88,1.15 \%$ of organic matter, $0.061 \%$ of total salt, $10 \%$ of lime and with phosphorus and potassium of 6.6 and $140 \mathrm{~kg} / \mathrm{ha}$, respectively. The long-term average of total precipitation was determined as $384.9 \mathrm{~mm}, 308 \mathrm{~mm}$ in 2003 and $272.4 \mathrm{~mm}$ in 2004 (Fig. 1). The average temperature in the experimental years was high in 2003, but it was similar to the longterm average in 2004.

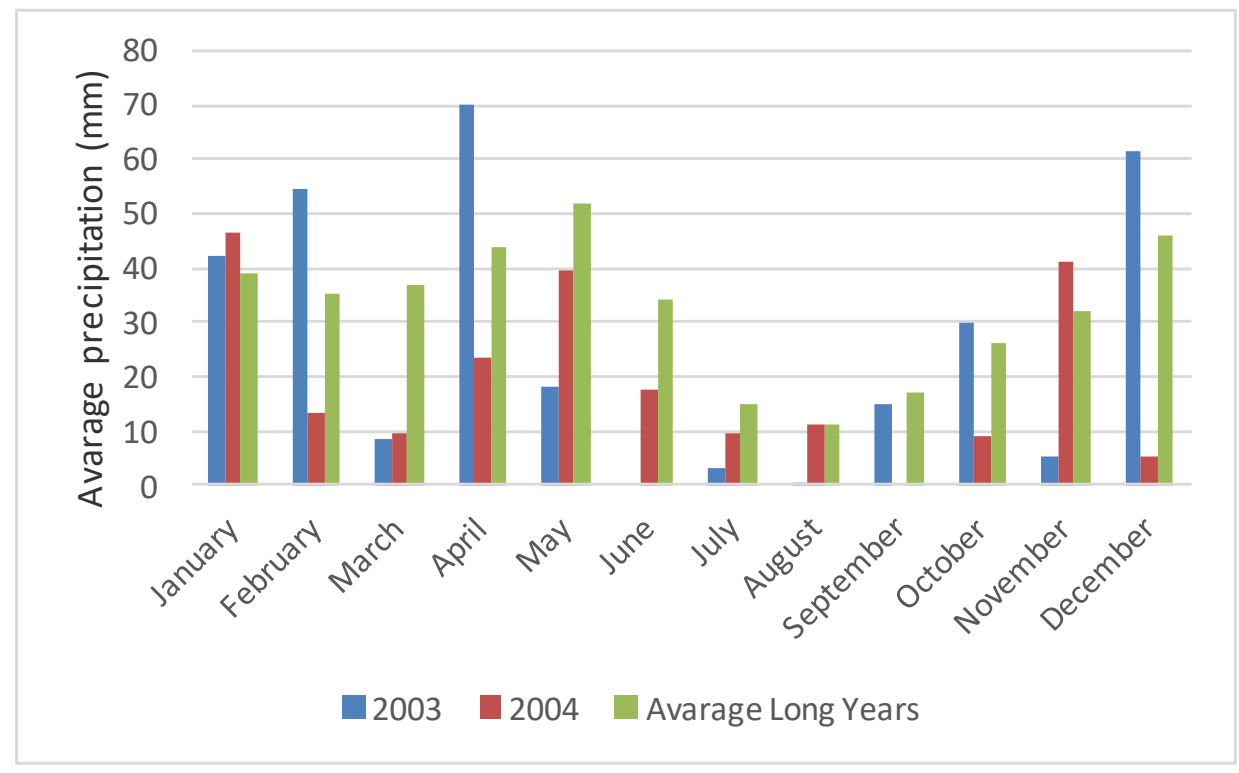

Figure 1. Monthly precipitation for the years of 2003 and 2004 and long-term average in Ankara 


\section{Materials and treatments}

The experiment was conducted complete blocks design with three replications in 2003-2004 years. Within the second and third year of the experiment established in 2002, the effects of the fertilizer applications applied to smooth brome plant were examined within the following years. This research was conducted in two separate experiments under irrigated and non-irrigated conditions. Smooth brome (Bromus inermis L.) (15 kg ha $\mathrm{kg}^{-1}$ ) seed populations characteristic was used as seed material. Ammonium sulphate, manure, poultry manure and as a green manure common vetch (Vicia sativa L.) were used as fertilizer materials in the experiment. The applications were determined as smooth brome (control), smooth brome + ammonium sulphate, smooth brome + barnyard manure, smooth brome + poultry manure, smooth brome + green manure. In the experiment, the parcels were at the length of $4 \times 2.4 \mathrm{~m}$ and smooth brome and vetch were planted as 12 rows at the row interval of $20 \mathrm{~cm}$ in alternative orders in the parcels where vetch is planted $\left(100 \mathrm{~kg} \mathrm{ha}^{-1}\right)$ for the purpose of green manure to 6 rows at the row interval of $40 \mathrm{~cm}$. The vetch was mixed into the soil by being harvested from the surface of the soil when it reached to $50 \%$ blooming period (Karatas, 2004). In the fertilizer applications, barnyard manure of 20 tons $^{-1} a^{-1}$ and poultry manure of 10 tons $\mathrm{ha}^{-1}$ were mixed into the depth of $0-20 \mathrm{~cm}$ of the soil in the spring ploughing. Ammonium sulphate manure was applied as $100 \mathrm{~kg} \mathrm{ha}^{-1}$ within the seedling period after planting. In the experiment conducted under irrigated conditions, the decision was taken according to the precipitation condition of traditional flood irrigation. Traditional flood irrigation was made for once in March 2003 and for twice in March and April due to the precipitation decrease in March and April 2004.

In the irrigated and non-irrigated plots, harvesting was performed at the beginning of flowering. The harvested plant samples were dried until reaching a constant mass to obtain dry matter yields at $70{ }^{\circ} \mathrm{C}$ (Martin et al.,1990). After the weed samples were ground, the nitrogen ratio was determined by the Kjeldahl method. The determined nitrogen ratios were multiplied by a coefficient of 6.25 and the crude protein ratio was calculated in the dry weeds. The crude protein yields were determined by proportioning the crude protein ratios obtained with dry matter yields.

\section{Statistics}

Variation analyses of the obtained data were conducted separately according to significance levels of 5\% and 1\% based on the General Linear Model of Statistical Analysis Systems (SAS) program. LSD test was used to compare treatment means at a $5 \%$ significance level, when differences emerged between fertilizer applications.

\section{Results and discussion}

The mean values and variance analysis results of effects of chemical and organic fertilizer on the examined properties in the smooth brome cultivated under irrigated and non-irrigated conditions are given in Table 1. The height of the plant was not affected by the application during the years when the research was conducted. Considering the two-year average, the highest plant height was obtained by application of ammonium sulphate and manure under irrigated conditions. Under the non-irrigated conditions, the highest plant height was obtained from green fertilizer application with $70 \mathrm{~cm}$. Karakurt 
and Ekiz (2000) reported that different nitrogen and manure applications in Ankara conditions did not affect the plant height of the smooth brome.

In statistical evaluation regarding the crude protein ratio, the difference between the applications in 2003 and 2004 was found to be significant at a level of $1 \%$ under irrigated conditions and 5\% under non-irrigated conditions (Table 1). Under irrigated conditions, the highest crude protein ratios in 2003 and 2004 were obtained from ammonium sulphate with 13.93 and $14.16 \%$, respectively. The values we obtained regarding the crude protein ratio under irrigated conditions are similar to those of Serin (1996b). The crude protein ratio values in the non-irrigated conditions according to the two years average were obtained between the ranges of 11.8-14.2\%. The values obtained by Serin (1996a) and Karakurt and Ekiz (2000) are similar to the values of crude protein ratio we obtained from our research. Albayrak et al. (2011) and Albayrak and Ekiz (2005) obtained crude protein ratio in smooth brome as $10.79 \%$ and $10.30 \%$, respectively. It was determined that while the crude protein ratio values were affected by different fertilizer applications in both years, they were not affected by irrigation.

Table 1. The means of the effects of different fertilizer applications on the properties of smooth brome under irrigated and non-irrigated conditions on plant height (PH), crude protein ratio $(C P R)$, crude protein yield (CPY) and dry matter yield (DMY)

\begin{tabular}{|c|c|c|c|c|c|c|c|c|}
\hline \multirow[b]{2}{*}{ Applications } & \multicolumn{4}{|c|}{ Irrigated conditions } & \multicolumn{4}{|c|}{ Nonirrigated conditions } \\
\hline & $\begin{array}{l}\mathbf{P H} \\
(\mathbf{c m})\end{array}$ & $\begin{array}{l}\text { CPR } \\
(\%)\end{array}$ & $\begin{array}{c}\text { CPY } \\
\left(\text { t ha }^{-1}\right)\end{array}$ & $\begin{array}{c}\text { DMY } \\
\left(\text { t ha }^{-1}\right)\end{array}$ & $\begin{array}{l}\mathbf{P H} \\
(\mathbf{c m})\end{array}$ & $\begin{array}{c}\text { CPR } \\
(\%)\end{array}$ & $\begin{array}{c}\text { CPY } \\
(\text { t ha-1 })\end{array}$ & $\begin{array}{c}\text { DMY } \\
\left(t \text { ha }^{-1}\right)\end{array}$ \\
\hline & \multicolumn{4}{|c|}{2003} & \multicolumn{4}{|c|}{2003} \\
\hline Control & 95 & $13.4 a b^{* *}$ & $0.59 \mathrm{cb}^{* *}$ & $4.41 b^{* *}$ & 67 & $13.2 \mathrm{ab}^{*}$ & $0.18 \mathrm{dc}^{* *}$ & $1.38 \mathrm{c} * *$ \\
\hline Ammonium Sulphat & 100 & $13.9 \mathrm{a}$ & $0.93 a$ & $6.70 \mathrm{a}$ & 65 & $13.9 \mathrm{a}$ & $0.22 b c$ & $1.58 \mathrm{c}$ \\
\hline Manure & 101 & $12.4 \mathrm{c}$ & $0.65 b$ & $5.26 \mathrm{~b}$ & 71 & $12.0 \mathrm{~b}$ & $0.31 \mathrm{a}$ & $2.57 \mathrm{a}$ \\
\hline Poultry manure & 99 & $12.7 \mathrm{bc}$ & $0.65 b$ & $5.06 \mathrm{~b}$ & 70 & $12.8 \mathrm{ab}$ & $0.27 \mathrm{ab}$ & $2.08 \mathrm{~b}$ \\
\hline Green manure & 95 & $11.3 \mathrm{~d}$ & $0.49 \mathrm{c}$ & $4.34 \mathrm{~b}$ & 70 & $12.0 \mathrm{~b}$ & $0.16 \mathrm{~d}$ & $1.31 \mathrm{c}$ \\
\hline Mean & 97.8 & 12.7 & $0.66 \mathrm{~A}^{* *}$ & $5.15 \mathrm{~A}^{*}$ & 68.7 & 12.8 & 0.23 & 1.78 \\
\hline \multirow[t]{2}{*}{ LSD } & 8.72 & 0.90 & 0.151 & 11.11 & 11.13 & 1.35 & 0.056 & 0.374 \\
\hline & \multicolumn{4}{|c|}{2004} & \multicolumn{4}{|c|}{2004} \\
\hline Control & 96 & $12.6 \mathrm{bc} * *$ & $0.35 \mathrm{bc} * *$ & $2.76 a b^{*}$ & 68 & $13.0 b^{*}$ & $0.23 \mathrm{a}^{*}$ & $1.75 \mathrm{ab}^{*}$ \\
\hline Ammonium Sulphat & 103 & $14.1 \mathrm{a}$ & $0.45 \mathrm{a}$ & $3.17 \mathrm{a}$ & 62 & $14.5 \mathrm{a}$ & $0.21 \mathrm{a}$ & $1.42 \mathrm{ab}$ \\
\hline Manure & 100 & $11.6 \mathrm{dc}$ & $0.28 \mathrm{c}$ & $2.39 b$ & 64 & $11.6 b$ & $0.13 b$ & $1.14 \mathrm{~b}$ \\
\hline Poultry manure & 96 & $13.6 \mathrm{ab}$ & $0.39 \mathrm{ab}$ & $2.92 \mathrm{ab}$ & 66 & $12.5 b$ & $0.25 \mathrm{a}$ & $1.99 \mathrm{a}$ \\
\hline Green manure & 99 & $11.0 \mathrm{~d}$ & $0.27 \mathrm{c}$ & $2.42 \mathrm{~b}$ & 70 & $12.0 \mathrm{~b}$ & $0.22 \mathrm{a}$ & $1.85 \mathrm{a}$ \\
\hline Mean & 98.7 & 12.6 & $0.35 \mathrm{~B}$ & $2.73 \mathrm{~B}$ & 65.8 & 12.7 & 0.207 & 1.63 \\
\hline \multirow[t]{2}{*}{ LSD } & 9.10 & 1.39 & 0.086 & 0.535 & 10.52 & 1.54 & 0.071 & 0.641 \\
\hline & \multicolumn{4}{|c|}{ Two years average } & \multicolumn{4}{|c|}{ Two years average } \\
\hline Control & 96 & $13 b^{* *}$ & $0.47 b^{* *}$ & $3.58 \mathrm{bc} * *$ & 68 & $13.1 b^{* *}$ & $0.21 b^{*}$ & $1.57 \mathrm{bc} *$ \\
\hline Ammonium Sulphat & 101 & $14 \mathrm{a}$ & $0.69 \mathrm{a}$ & $4.93 \mathrm{a}$ & 64 & $14.2 \mathrm{a}$ & $0.21 b$ & $1.50 \mathrm{c}$ \\
\hline Manure & 100 & $12 \mathrm{c}$ & $0.47 b$ & $3.83 b c$ & 68 & $11.8 \mathrm{c}$ & $0.22 \mathrm{ab}$ & $1.85 \mathrm{ab}$ \\
\hline Poultry manure & 97 & $13.1 \mathrm{~b}$ & $0.52 b$ & $3.99 b$ & 68 & $12.6 \mathrm{cb}$ & $0.26 \mathrm{a}$ & $2.03 \mathrm{a}$ \\
\hline Green manure & 97 & $11.1 \mathrm{~d}$ & $0.38 \mathrm{c}$ & $3.38 \mathrm{c}$ & 70 & $12 \mathrm{c}$ & $0.18 b$ & $1.58 \mathrm{bc}$ \\
\hline Mean & 98.2 & 12.7 & 0.51 & 3.94 & 67.26 & 12.8 & 0.21 & 1.71 \\
\hline LSD & 3.63 & 0.45 & 0.048 & 0.566 & 4.28 & 0.55 & 0.026 & 0.341 \\
\hline
\end{tabular}

$*^{*} p<0.01, * p<0.05$. Means within the same column followed by the same letter are not significantly different 
In the first year of the research, the highest crude protein yield was obtained from the ammonium sulphate application under irrigated conditions and this was followed by manure and poultry manure applications. The highest average crude protein yield was obtained from the application of chemical fertilizer with $0.69 \mathrm{t} \mathrm{ha}^{-1}$ and this was followed by poultry manure application with $0.52 \mathrm{t} \mathrm{ha}^{-1}$. Yolcu (2011) reported that the highest crude protein yield was obtained from manure and chemical fertilizer applications. In the second year of the research, yields of crude protein decreased significantly due to the decrease in dry matter yields. Ozaslan et al. (2011) stated that there was an increase in the amount of sod-boinding by the increase in precipitation and that the same problem was encountered again 3-4 years after the year of establishment. The crude protein yields of smooth brome decreased in the research due to irrigation and the fact that it was the $3^{\text {rd }}$ year of establishment.

Under non-irrigated conditions, it was found that there was a significant decrease only in the application of manure in the second year, but there was no significant decrease in other applications and accordingly the difference between the years was not significant (Table 1). In the first year, the highest crude protein yield was obtained from manure application with $0.31 \mathrm{t} \mathrm{ha}^{-1}$. In the second year, values close to each other were obtained from all other applications except manure. Considering the two-year general average, the highest value was obtained from the application of poultry manure with $0.26 \mathrm{t} \mathrm{ha}^{-1}$. Karakurt and Ekiz (2000) obtained the highest crude protein yield from $120 \mathrm{~kg} \mathrm{ha}^{-1}$ of nitrogen application and this was followed by manure application with $3 \mathrm{t} \mathrm{ha}^{-1}$. The difference between applications and years may be caused by the amount of precipitation of that year, and thus the fertilizer efficiencies (Fig. 1).

Irrigation improves the effectiveness of chemical fertilizers. The highest dry matter yield in smooth brome was obtained from ammonium sulphate application in both years under irrigated conditions. In organic fertilizers, values close to each other were obtained in manure and poultry manure and values close to the control value were obtained in green fertilizer. The highest dry matter yield was obtained from chemical fertilizer application with $4.93 \mathrm{t} \mathrm{ha}^{-1}$. This application was followed by poultry manure application with $3.99 \mathrm{t} \mathrm{ha}^{-1}$. The dry matter yield values obtained in 2003 decreased by half in 2004, the third year of the research (Table 1). The decrease in yield may be caused by the sod-boinding occurred in the smooth brome due to irrigation and the fact that the field was in its third year. The values we obtained in our research for the dry matter yield of smooth brome cultivated under irrigated conditions are consistent with the values obtained by Serin (1996b) and Tukel et al. (2001). Serin et al. (1998) reported that and that smooth brome yield decreased in the $2^{\text {nd }}$ and $3^{\text {rd }}$ years compared to the first year under irrigated conditions.

The highest dry matter yield of smooth brome cultivated under non-irrigated conditions was obtained from the manure in the first year of the research, from poultry manure and green fertilizer in the second year and from poultry manure in the two-year average. These results show that organic fertilizers have more effect on plant yields in arid and semi-arid conditions. According to the consolidated years average, the highest dry matter yield was obtained from the application of poultry manure with $2.03 \mathrm{t} \mathrm{ha}^{-1}$. The lowest dry matter yield was obtained from control and chemical fertilizer applications. 


\section{Conclusion}

According to the research results, it was determined that crude protein ratio, crude protein yield and dry matter yield were affected by different fertilizer applications under both irrigated and non-irrigated conditions. It was found that the efficiency of chemical fertilization was higher under irrigated conditions, but that the sod-boinding problem observed in smooth brome was higher due to the effect of irrigation. This situation significantly decreased the dry matter yields. It was determined that organic fertilizers were more efficient than chemical fertilizers under arid and semi-arid conditions. This result is of importance for producers carrying out conventional agriculture. Also, it is a known fact that the use of organic fertilizer is more profitable in the long term, despite the fact that there is a difference between chemical fertilization applications and organic fertilizers in irrigated agricultural lands.

Acknowledgements. This study was presented as a poster at the $10^{\text {th }}$ National Field Crops Congress.

\section{REFERENCES}

[1] Albayrak, S., Ekiz, H. (2005): An investigation on the establishment of artificial pasture under Ankara's ecological conditions. - Turkish Journal of Agriculture and Forestry 29(1): 69-74.

[2] Albayrak, S., Türk, M., Yuksel, O., Yilmaz, M. (2011): Forage yield and the quality of perennial legume-grass mixtures under rainfed conditions. - Notulae Botanicae Horti Agrobotanici Cluj-Napoca 39(1): 114.

[3] Alçiçek A, Kılıç A, Ayhan V, Özdoğan, M. (2010): Forage Production and Problems in Turkey. - Turkey Agricultural Engineer VII. Technical Congress, 11-15 January 2010, Ankara.

[4] Bender, D., Erdal, İ., Dengiz, O., Gürbüz, M., Tarakçığlu, C. (1998): The Effects of Some Organic Materials on Some Physical Properties of a Clay Soil. International Symposium on Arid Region Soil. - International Agrohydrology Research and Training Center, Menemen, İzmir, pp. 506-510.

[5] Bulluck Iii, L. R., Brosius, M., Evanylo, G. K., Ristaino, J. B. (2002): Organic and synthetic fertility amendments influence soil microbial, physical and chemical properties on organic and conventional farms. - Applied Soil Ecology 19(2): 147-160.

[6] Çakmakçı, S., Aydınoğlu, B., Arslan, M., Özyiğit, Y., Tetik, M., Bilgen, M. (2004): Determination of optimum fall sowing date for some forage species in terms of forage yield of rangelands in the continental climate zones. - Mediterranean Agricultural Sciences 17(1): 43-47.

[7] Carpenter-Boggs, L., Kennedy, A. C., Reganold, J. P. (2000): Organic and biodynamic management effects on soil biology. - Soil Science Society of America Journal 64(5): 1651-1659.

[8] Emerenciano Neto, J. V., Pereira, G. F., Difante, G. D. S., Oliveira, L., Santos, W., Gurgel, M. (2016): Production and structure of massai grass pastures fertilized with animal manures. - Boletim de Indústria Animal 73(2): 111-117.

[9] Golijan, J., Popović, A., Dimitrijević, B., Kolarić, L., Živanović, L. (2017): The status of the forage organic production in the Republic of Serbia. - Agriculture \& Forestry/Poljoprivreda i Sumarstvo 63(3): 177-187.

[10] Hongrong, Z. Z. F. H. Z., Xuerui, Z. X. L. (2000): Effect of Sludge Utilization on Smooth Brome Growth. - Acta Agrestia Sinica 2: 010. 
[11] Karakurt, E., Ekiz, H. (2000): Effects of nitrogen fertilizer doses on important agronomic characters in some forage grasses. - Journal of Central Research Institute for Field Crops 9: $1-11$.

[12] Karataş, N. (2004): The effect of some fertilizer application in smooth bromegrass (Bromus inermis Leyss.) to plant development under irrigated and nonirrigated conditions. - Master Thesis, University of Ankara Institute of Science.

[13] Marinari, S., Masciandaro, G., Ceccanti, B., Grego, S. (2000): Influence of organic and mineral fertilisers on soil biological and physical properties. - Bioresource Technology 72(1): 9-17.

[14] Martin, R.C., Harvey, H.D. ve Smith, D.L. (1990): Intercropping corn and soybean for silage in a cool temperate region; yield, protein and economic effects. - Field Crops Research, 23: 295-310.

[15] Moreno-Reséndez, A., Cantú Brito, J. E., Reyes-Carrillo, J. L., Contreras-Villarreal, V. (2017): Forage maize nutritional quality according to organic and inorganic fertilization. - Scientia Agropecuaria 8(2): 127-135.

[16] Nazlı, R. I., Kuşvuran, A., Inal, I., Demirbaş, A., Tansi, V. (2014): Effects of different organic materials on forage yield and quality of silage maize (Zea mays L.). - Turkish Journal of Agriculture and Forestry 38(1): 23-31.

[17] Özaslan Parlak, A., Ekiz, H. (2011): Effects of Pitting and Nitrogenous Fertilizer Aplications on Elemination of Sod-Boinding in Smooth brom grass (Bromus inermis leyss.). $-10^{\text {th }}$ Turkey Field Crops Congress, 12-15 September 2011, Bursa.

[18] Razec, I., Razec, M., Noaghea, M., Ujupan, G. (2009): Forage productivity and soil fertility under organic fertilizer conditions on Agrostis capillaries pastures. - Scientific Papers Animal Science and Biotechnologies 42(1): 205-209.

[19] Serin, Y. (1996a): Research on the effects of different row space and fertilizers applied on smooth brome (Bromus inermis Leyss.) grown on erzurum dried conditions on hay and and crude protein ratio. - Turkey $3^{\text {rd }}$ Meadow and Pasture Congress, 17-19 June, Erzurum.

[20] Serin, Y. (1996b): Research on the effects of different row space and fertilizers applied on smooth brome (Bromus inermis Leyss.) grown on erzurum irrigated conditions on hay and crude protein ratio. - Turkey $3^{\text {rd }}$ Meadow and Pasture Congress, 17-19 June, Erzurum.

[21] Serin, Y., Gökkuş, A., Tan, M., Koç, A., Çomakl1, B. (1998): Determination of suitable forage crop species and their mixtures for meadow establishment. - Turkish Journal of Agriculture and Forestry 22(1): 13-20.

[22] Shiralipour, A., McConnell, D. B., Smith, W. H. (1992): Physical and chemical properties of soils as affected by municipal solid waste compost application. - Biomass and Bioenergy 3(3-4): 261-266.

[23] Sönmez, İ., Kaplan, M., Sönmez, S. (2008): Effect of chemical fertilizers on environmental pollution and its prevention methods. - Batı Akdeniz Agricultural Research Institute DERIMM Journal 25(2): 24-34.

[24] Tükel, T., Hatipoglu, R., Polat, T., Can, E., Yılmaz, Ş., Çeliktaş, N., Kökten, K. (2001): Research on the Forage Yields of Some Perennial, Grasses and Legumes Under Irrigated Conditions of Çukurova and Southesthern Regions. - GAP II. Agricultural Congress, 2426 October, Şanliurfa.

[25] Will, J. (2012): Organic Forage: A Strategy for Planning Future Cropping. https://businesswales.gov.wales (accessed March 21, 2017).

[26] Yolcu, H. (2011): The effects of some organic and chemical fertilizer applications on yield, morphology, quality and mineral content of common vetch (Vicia sativa L.). Turkish Journal of Field Crops 16(2): 197-202.

[27] Yolcu, H., Okçu, M., Tan, M. (2014): Current situation of organic roughage production in Turkey. - Yuzuncu Y11 University Journal of Agricultural Science 24(2): 201-209. 